\title{
小脳橋角部腫瘍の神経耳科学的特徵
}

一とくに聴神経腫瘍以外の腫瘍を中心に一

$\begin{array}{lcccr}\text { 安田 } & \text { 健二・渡辺 } & \text { 行雄 } \cdot 大 \text { 井 } & \text { 秀哉・中川 } \\ \text { 小林 } & \text { 英人・麻生 } & \text { 伸・神田 } & \text { 憲一・浅井 } & \text { 正嗣 } \\ \text { 水越 } & \text { 鉄理・高久 } & \text { 晃* } & & \end{array}$

\section{Otoneurological Evaluation of Other Cerebellopontine Angle Tumors in Comparison with Acoustic Tumor}

\author{
Kenji Yasuda, Yukio Watanabe, Hideya Ohi, Hajime Nakagawa, \\ Hideto Kobayashi, Shin Aso, Ken-ichi Kanda, Masatsugu Asai, \\ Kanemasa Mizukoshi and Akira Takaku \\ (Toyama Medical and Pharmaceutical University)
}

\begin{abstract}
We reported the otoneurological findings of 5 cerebellopontine angle tumors other than acoustic neuromas, and compared the results with those of 11 cases of acoustic neuroma. The signs and symptoms of other cerebellopontine angle tumors were not uniform, thus, the differential diagnosis between other cerebellopontine angle tumors invasing VIII nerve and acouctic neuroma was very difficult.
\end{abstract}

Key words: cerebellopontine angle tumor, acoustic tumor, otoneurological findings, MRI

はじめに

小脳橋角部 (cerebellopontine angle：以下 $\mathrm{CPA}$ と略す）に発生する腫瘍には，聴神経腫 瘍をはじめとして, 䯣膜腫, 類上皮腫, 三叉神 経鞘腫などの腫瘍がある。(以下非聴神経腫瘍 と略す.）このらち聴神経腫瘍は，小脳橋角部 腫瘍の約 $80 \%$ を占め ${ }^{122)}$, また以前から, 神経 耳科学的に大いに興味を持たれてきた腫瘍であ る. その反面, 非聴神経腫瘍については, 聴神 経腫瘍に比べて注目を集めることは少なかった． この点, 非聴神経腫瘍はある程度大きくなるま
で臨床的に silent であることが多いが，聴神経 をはじめとする脳神経を侵襲したり，小脳や脳 幹部を圧迫することが多くみられた。したがっ て, 時に, 聴神経腫瘍と似た症状や検査所見を 呈することがあり，聴神経腫瘍の鑑別診断が問 題となることがあった.

一方, 最近の画像診断の発達により, 内耳道 内に限局したいわゆる “ear tumor” の診断”が 可能になってきており，脳幹に圧迫を及ぼして いる chronology の進んだ聴神経腫痬4) は比較 的少なくなってきた。“ear tumor”の段階では， 
非聴神経腫瘍との鑑別は比較的容易であるが, “Bruns 眼振”を認める聴神経腫瘍も時にみら れる.したがって，小脳橋角部に侵入した聴神 経腫瘍と非聴神経腫瘍との鑑別が臨床的になお 注目されている。これら比較的進展した聴神経 腫瘍と非聴神経腫瘍について, 画像診断が普及 した段階での鑑別についての検討は比較的少な いのが現況である.

今回, 私どもは, 手術所見で腫瘍の発生部位 や発育方向が確認できた小脳橋角部の非聴神経 腫瘍（髄膜腫 3 例, 類上皮腫 1 例, 三叉神経鞘 腫 1 例）を経験したので，現段階において，一 般的な非聴神経腫瘍と聴神経腫瘍を比較し, そ の特徵を検討して報告する.

\section{対象および神経耳科学的検査}

対象症例は昭和56年 4 月より昭和 61 年 9 月ま でに当科神経耳科外来を受診し, 神経耳科検査 後, 脳神経外科にて小脳橋角部の非聴神経腫瘍 として確認された症例 5 例である。その内訳は, 髄膜腫 3 例, 類上皮腫 1 例, 三叉神経鞘腫 1 例 であった。

めまいの性状を中心とした現病歴の検討, 聴 覚系の検查として, 純音聴力検査, 他覚的聴覚 検査の ABR などを行った. 平衡機能検査とし て, Frenzel 眼鏡による眼振観察, ENG（時定 数 3 秒) 記録による自発眼振検査, 注視眼振検 査, 頭位眼振検査, 温度刺激眼振検査（冷温交 互 air calorization, $24^{\circ} \mathrm{C} 50^{\circ} \mathrm{C}, 60$ 秒通気流, $\mathrm{CP}, \mathrm{DP} \%$ 緩徐相速度で評価）ならびに固視 抑制障害 (failure of fixation suppression: 以 下 FFS と略す), 視標追跡検査 (ETT), 視運動 性眼振検査（以下 OKN と略す： $1 \% \mathrm{sec}^{2} 100$ 秒 間加速度刺激 Jung 型ドラム：最大緩徐相速度 で評価)，振子様回転検査 (VOR, V-VOR : 0.1 $\mathrm{Hz}, \pm 120^{\circ}$ 振幅, 最大 $74.5 \% \mathrm{sec}$ 開眼閉眼で回 転：利得で評価）, 重心動摇計による電気的身 体動摇検查 (Galvanic body sway test : 以下 GBST と略す：0.2 mA，0.4 mA 10回加算）な ぞ総合的平衡機能検査を行った。 また画像診断 として, 側頭骨の単純エックス線, CT-scan,
必要に応じて air-CT, MRI などを施行した. 検査ならびにその判定についての詳細は当教室 の情報処理システムに従って評価した5)6).

\section{結果}

対象症例 5 例は表 1 に示した通りである. 全 症例に扮いて脳神経外科にて, 腫瘍の全摘術, または亜全摘術が行われ, 病理学的診断がなさ れた。

各症例について, 以下具体的に述べる. 〈症例 1〉男性 50 才 三叉神経鞘腫 主訴: 左耳鳴, 左聴力低下, 左側頭部頭重感 初診：1982年 1 月 21 日

現病歴：1981年 6 月頃より左側頭部頭重感出現, 同年10月頃より左耳鳴, 左聴力低下を訴えた。 また左舌半分の味覚低下を訴えた。めまいはな かった。

既往歴，家族歴：特記すべさことなし

神経学的所見：（1982年 1月）

脳神経障害 : 左第 $\mathrm{V}$ 脳神経支配領域の知覚 (VIII以外) 低下

神経耳科学的所見 :

平衡機能検査

ETT：水平 垂直方向ともに smooth 自発眼振 なし

右向き注視眼振 $(+)$ 頭位眼振 なし 温度眼振検査 : $1 \mathrm{t}-\mathrm{CP}(+) \quad 100 \%$ （最大 緩徐相速度) $\operatorname{FFS}( \pm)$ (右側のみ)

$\mathrm{OKN}$ : 水平方向 両抑制 (右向 $30 \%$ sec 左向 $26 \%$ sec)

垂直方向 未検

GBST : 未検

振子様回転検查 : VOR V-VOR 未検 恥覚検査

純音聴力検査

右 平均 $7 \mathrm{~dB}$ 水平型

左平均 $11 \mathrm{~dB}$ やや山型

$\mathrm{ABR}$ 左 III, $\mathrm{N}$ 波無反応

X-P 所見 :

内耳道 左右差なし 
CT 左 CPA $飞$ low density area (+) $(28 \times 17 \mathrm{~mm})$ (図 1 )

手術所見：左小脳橋角部に充実性の腫瘍を認め, 橋小脳の一部を圧迫. 腫瘍の表面を菲薄化した 第VII, 第UIII脳神経が走行していた。（内耳道孔 も確認された)

〈症例 2 男性 28 才右類上皮腫 主訴：右顔面の疼痛, 右舌根部痛

初診：1986年 7 月29日

現病歴：1982年頃上り右第 $\mathrm{V}$ 脳神経領域の疼痛, 右舌根部痛が出現. 徐々に増悪傾向をたどる. めまいはなかった。

既往歴, 家族歴：特記すべきことなし 神経学的所見 :

脳神経障害 : 右第 $V$ 神経第 2 枝領域の知覚低 下 (VIII以外)

神経耳科学的所見：

平衡機能検査

ETT: 水平 垂直方向ともに smooth 左向自発眼振 $(+)$

注視眼振 なし

左向方向固定性頭位眼振 $(+)$

温度眼振検査 : 右 $\mathrm{CP}(+) 31 \%$

$\mathrm{DP}(-) 6 \%$ FFS $(-)$

$\mathrm{OKN}$ : 正常 (右向 $84 \%$ sec 左向 $89 \%$ sec)

GBST : 未検

振子様回転検査: VOR 利得 正常

(右 0.89 左 0.74 )

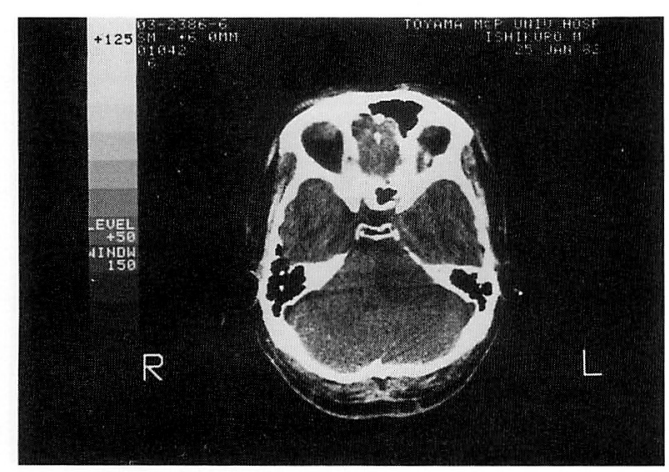

図 1
V-VOR 利得 正常

(右 1.01 左 1.05 )

聴覚検査

純音聴力検查

右 平均 $10 \mathrm{~dB}$ 水平型

左 平均 $10 \mathrm{~dB}$ 水平型

ABR 正常

$\mathrm{X}-\mathrm{P}$ 所見 :

内耳道 左右差なし

air-CT 右内耳道に air 侵入 (+) (図 2 )

MRI 右 CPA に high signal area $(+)(27 \times 27$ $\mathrm{mm}$ )

手術所見：右 CPA に被膜に包まれた軟実質性 の腫瘍を認めた・・VI XII のいずれの脳神経に も絡久つく形で腫瘍が充満していたが，圧迫所 見は明らかでなかった。

〈症例 3 〉女性 55 才 右䯣膜腫

主訴：右側頭部痛

初診 : 1985年 4 月 5 日

現病歴：1985年 3 月15日, 突然右側頭部の頭痛 が出現. 頭痛は持続した. めまいはなかった.

既往歴, 家族歴：特記すべきことなし

神経学的所見：(1985年4月15日)

脳神経障害 : 第UII脳神経以外に認めず

神経耳科学的所見：

平衡機能検査

$\mathrm{ETT}$ : 水平 垂直方向ともに ataxic

右向き自発眼振 $(+)$

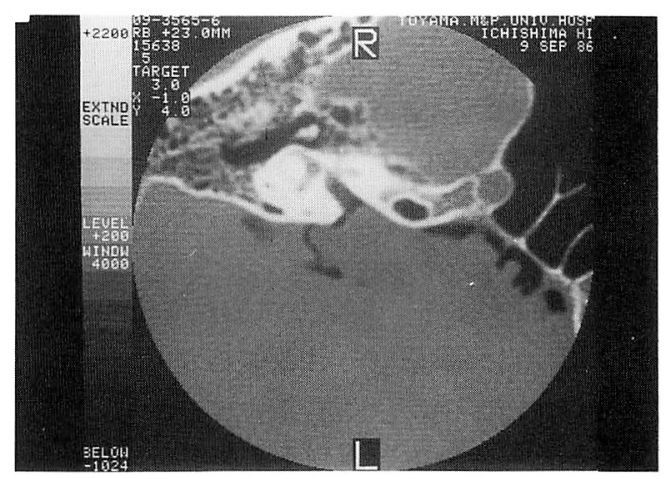

図 2 
注視眼振 なし

右向き方向固定性頭位眼振 $(+)$

温度眼振検査 : CP (-) 7\%

$$
\text { 右向 DP (+) } 25 \%
$$

OKN : 両抑制（右向 $44 \%$ sec 左向 $34 \%$ sec)

GBST : 未検

振子様回転検査：VOR 利得正常

$$
\begin{gathered}
\text { (右 } 0.44 \text { 左 } 0.58 \text { ) } \\
\text { V-VOR 利得 正常 } \\
\text { (右 } 0.89 \text { 左 } 0.94 \text { ) }
\end{gathered}
$$

聴覚検査

純音德力検査

$$
\begin{aligned}
& \text { 右 平均 } 22 \mathrm{~dB} \quad \mathrm{C}_{5} \mathrm{dip} \\
& \text { 左 平均 } 16 \mathrm{~dB} \text { 水平型 }
\end{aligned}
$$

$\mathrm{ABR}$ 右 波形の再現性に乏しかった。

$\mathrm{X}-\mathrm{P}$ 所見 :

内耳道 左右差なし

CT 右 CPA に high density area $(33 \times 33 \mathrm{~mm})$ 手術所見：中頡蓋窩に小脳と橋にはさまれたか たらで実質性の腫瘍を認めた。小脸脚にも接し ていた。

\section{〈症例 4〉女性 62 才 左髄膜腫}

主訴：左舌顎部痛

初診：1985年 2 月 7 日

現病歴：15年来続く左三叉神経痛, 動摇視によ るめまいが1980年頃より出現. 1982年頃より左 聴力低下を自覚した. 1984年頃より左口角, 左 外眼角のけい机んが出現した.

既往歴，家族歴：特記すべきことなし 神経学的所見：

脳神経障害 : 左第 V，第VII脳神経障害（VIII以 外)

神経耳科学的所見：

平衡機能検査

$\mathrm{ETT}$ : 水平 垂直方向ともに smooth 右向自発眼振 $(+)$ 注視眼振なし 右向方向固定性頭位眼振 $(+)$ 温度眼振検査：両側反応低下 （最大緩徐相速度 右向 $0 \%$ sec 左向 $\left.3^{\circ} / \mathrm{sec}\right)$

FFS (-)

$\mathrm{OKN}$ ：正常（右向 $63 \%$ sec 左向 52

$$
\% \text { sec) }
$$

GBST : 左無反応

振子様回転検査：VOR 利得 正常

(右 0.52 左 0.61 )

V-VOR 利得 正常

（右 1.00 左 1.08 )

聴覚検査

純音聴力検査

右平均 $35 \mathrm{~dB}$ 水平型
左 平均 $51 \mathrm{~dB}$ 高音障害型

$\mathrm{ABR}$ 左 $\mathrm{I}-\mathrm{V}$ 波潜時延長

$\mathrm{X}-\mathrm{P}$ 所見 :

内耳道 左右差なし

CT 左小脳橋角部に high density area $(32 \times$ $16 \mathrm{~mm}$ ) (図 3 )

手術所見：左小脳橋角部に実質性の腫瘍を認め る. 小脸，橋への圧排は軽度だが，第VII，第VIII 脳神経への圧迫が認められた。第 V脳神経は腫 瘍内に埋没していた。

〈症例 5〉女性 33 才左髄膜腫

主訴：後頭部痛

初診：1985年 3 月 22 日

現病歴：1980年頃より続く後頭部痛あり。めま い，聴力低下や耳鳴は認められない.

既往歴，家族歴：特記すべきこと無し

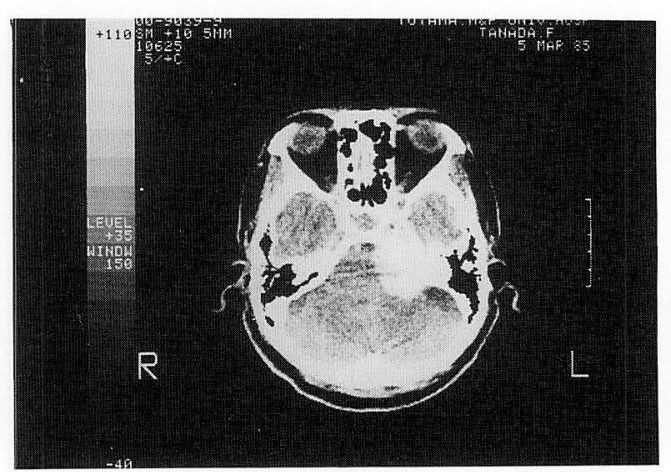

図 3 
神経学的所見 :

脳神経障害 : 第VIII脳神経も含め障害認めず 神経耳科学的所見 :

平衡機能検査

ETT : 水平 垂直方向ともに smooth 自発眼振なし

注視眼振なし 頭位眼振なし

温度性眼振 : 正常 冷刺激のみ 左右差なし

FFS (-)

$\mathrm{OKN}$ : 未検

GBST : 未検

振子様回転検査：VOR V-VOR 未検

聴覚検查（患側）

純音聴力検査

$$
\begin{aligned}
& \text { 右 平均 龍 (小児期上り) } \\
& \text { 左 平均 } 10 \mathrm{~dB} \text { 水平型 }
\end{aligned}
$$

$\mathrm{ABR}$ 左 正常

$\mathrm{X}-\mathrm{P}$ 所見 :

内耳道 左右差なし

CT 左 CPA に high density area $(74 \times 54 \mathrm{~mm})$ (図 4 )

手術所見 : 内耳道に近い小脳橋角部の側頭骨か ら発生したと思われる実質性の腫瘍を認めた。 第VII, 第VIII脳神経への圧迫所見もなく, また橋 や小脳への圧迫所見も少なかった。

症例1，3，4，50よ5に実質性腫瘍の場合， 手術所見と照らし合わせ検討を加えると, 腫瘍

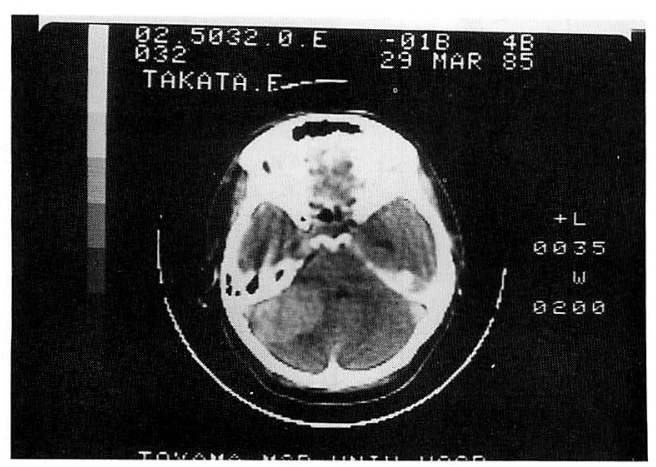

図 4
の発生部位と発育方向の圧排の程度が神経解剖 学的に症状や検查所見々一致していた。

また, 症例 2 は小脳橋角部を中心に, 第 $\mathrm{V}$ 脳 神経から第XII脳神経に伸展する形で腫瘍が発 育していた。しかし類上皮腫は，腫瘍そのもの が海綿状に近いものであったため, 周囲に対す る圧迫症状は，他の実質性腫瘍に比較すると弱 かった。このような点から, 症例 2 では臨床症 状も検查所見も silent であったものと推察した。

\section{考察}

一般に実質性腫瘍は発生部位や発育方向によ り臨床像, 検査所見が異なってくるので, 腫瘍 の性状も臨床像, 検査所見に影響を与えること が多い.この点, 症例 $1,3,4$, と症例 2,5 では, 異なる臨床像を示した。つまり, 症例 2,5 はそ れぞれ第叫脳神経や小脳脳幹をあまり侵襲せず に発育したため, 平衡機能検査の異常は少ない. このことは, 非聴神経腫瘍はその臨床像や検査 所見の特徵を一括して考虑することが難しいこ とを示唆している。

〈聴神経腫瘍と比較して〉

第ИIII脳神経を侵襲したり，小紋橋角部に圧迫 を及ぼした非聴神経腫瘍に遭遇した場合，聴神 経腫瘍との鑑別が問題とされてきた．今回の症 例 1，3，4 は第UII脳神経にも歹程度侵襲してお り,これらの症例と当科で経験した内耳道に限 局せずに小脳橋角部に突出した聴神経腫痬 11 例 （表 2 ）と比較し，その局在，大きさと検査所 見について検討してみた。

(1) 臨床症状

前庭機能の障害は腫瘍の進展が途く，中枢代 償機能が十分なされる余裕があるので, 聴神経 腫瘍では, 従来の報告の上らに初発症状として, めまいはそれほどみられない。一方, 非聴神経 腫瘍の初発症状としてめまいは少なく, 䯣膜腫 にみられるめまい怆, 自発性, 一過性, 反復性 動摇視ないしは回転性めまいが特徵的であると の報告899) もあるが，今回私どもが経験した症 例では認められなかった。

非聴神経腫瘍も発育が緩慢であるため症状が 


\begin{tabular}{|c|c|c|c|c|c|}
\hline 獣 & 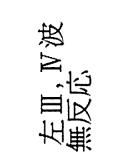 & $\begin{array}{l}\text { 细 } \\
H\end{array}$ & 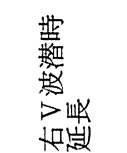 & 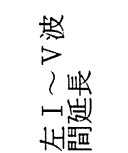 & $\begin{array}{l}\text { 距 } \\
H\end{array}$ \\
\hline 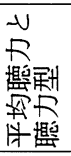 & $\begin{array}{l}\vartheta^{\text {㔀 }} \\
\exists \\
\text { 섴 }\end{array}$ & 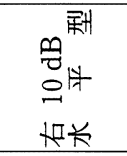 & 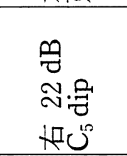 & 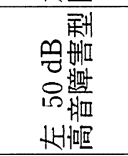 & 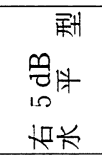 \\
\hline 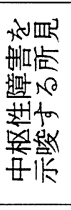 & 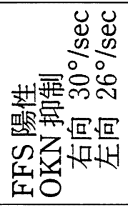 & 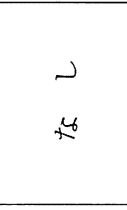 & 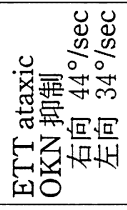 & 2 & 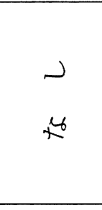 \\
\hline 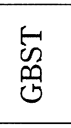 & $\begin{array}{l}\text { 然 } \\
\text { 长 }\end{array}$ & $\begin{array}{l}\text { 留 } \\
\text { 长 }\end{array}$ & 煫 & 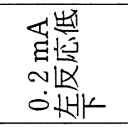 & $\begin{array}{l}\text { 然 } \\
\text { 长 }\end{array}$ \\
\hline $\begin{array}{l}\hat{A} \\
\hat{a} \\
\hat{R}\end{array}$ & 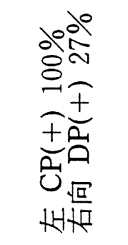 & 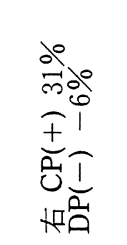 & 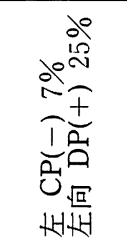 & 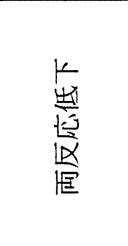 & 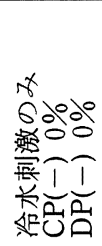 \\
\hline 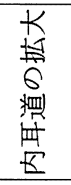 & $\begin{array}{l}- \\
+6\end{array}$ & $\begin{array}{l}\alpha \\
+6\end{array}$ & 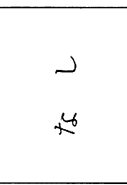 & $\begin{array}{l}-1 \\
+6\end{array}$ & $\begin{array}{l}-1 \\
+6\end{array}$ \\
\hline 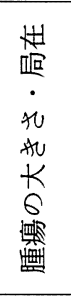 & 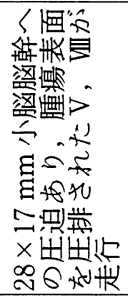 & 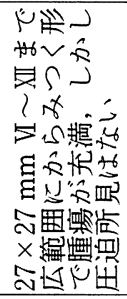 & 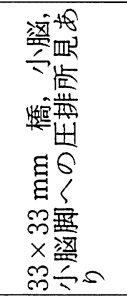 & 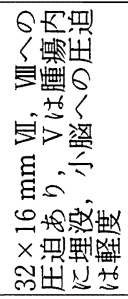 & 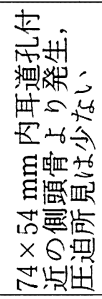 \\
\hline 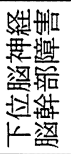 & 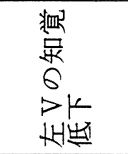 & 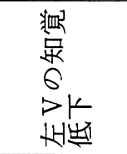 & $\begin{array}{l}-1 \\
+6\end{array}$ & 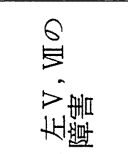 & 2 \\
\hline 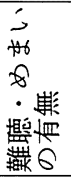 & 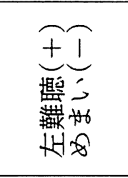 & 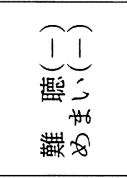 & 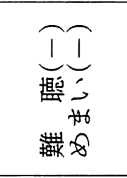 & 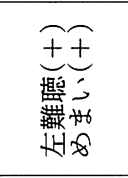 & 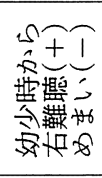 \\
\hline 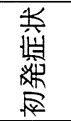 & 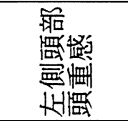 & 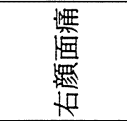 & 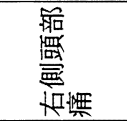 & 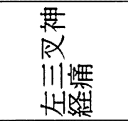 & 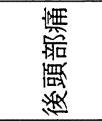 \\
\hline 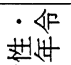 & 苕昔 & 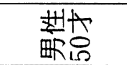 & 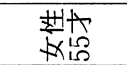 & 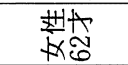 & $\underset{+\infty}{H}$ \\
\hline 点 & 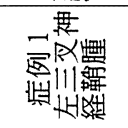 & 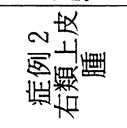 & 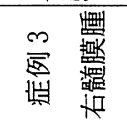 & 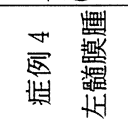 & 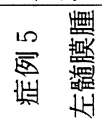 \\
\hline
\end{tabular}




\begin{tabular}{|c|c|c|c|c|c|c|c|c|c|c|c|}
\hline 獣 & 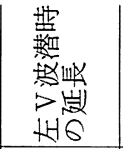 & 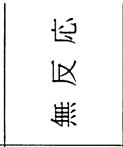 & 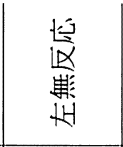 & 岕 & 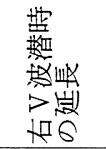 & 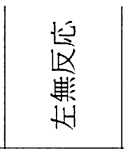 & 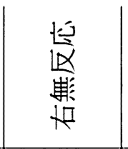 & 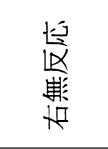 & 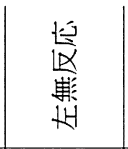 & 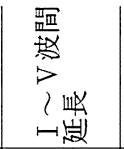 & $\begin{array}{c}x \\
6 \\
6 \\
+5 \\
+1 \\
+10\end{array}$ \\
\hline 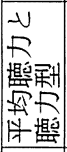 & 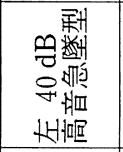 & 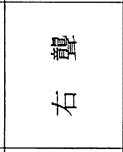 & H & 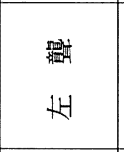 & 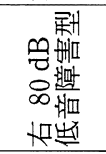 & 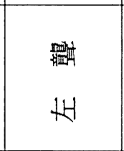 & 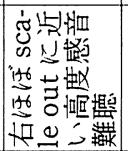 & $\begin{array}{l}\text { 踥迹 } \\
\text { Lए }\end{array}$ & 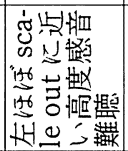 & 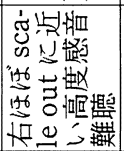 & 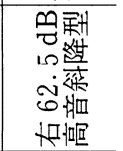 \\
\hline 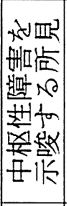 & 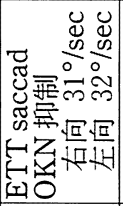 & +6 & 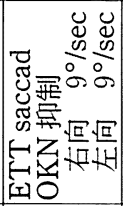 & 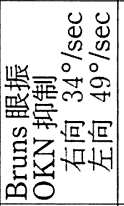 & $x^{6}$ & 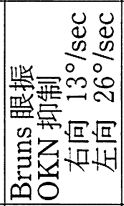 & 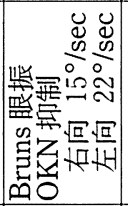 & 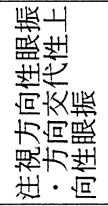 & +6 & $\begin{array}{l}-2 \\
+6\end{array}$ & 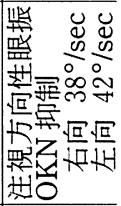 \\
\hline 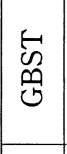 & 留 & 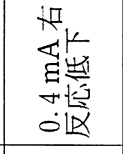 & \# & 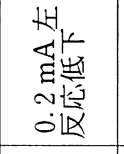 & 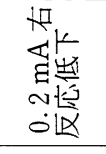 & 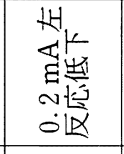 & 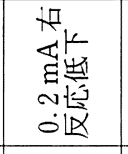 & 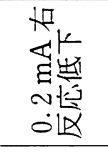 & 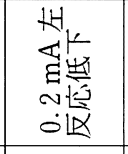 & 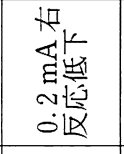 & 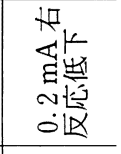 \\
\hline $\begin{array}{l}A \\
\hat{a} \\
\bar{R}\end{array}$ & 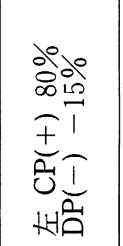 & 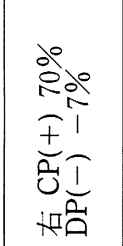 & 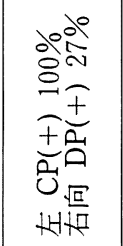 & 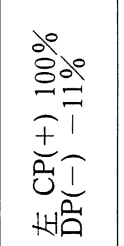 & 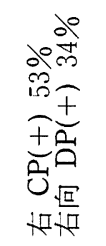 & $\frac{k}{\frac{1}{4 \pi}}$ & 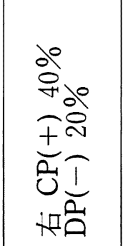 & 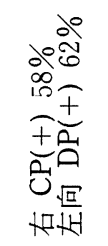 & 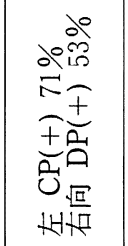 & 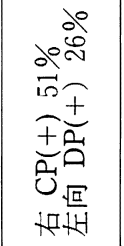 & 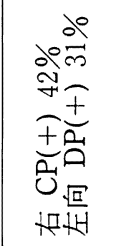 \\
\hline 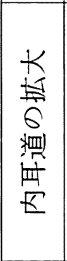 & 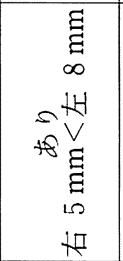 & 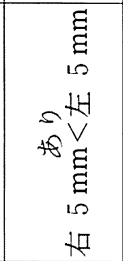 & $\begin{array}{r}E \\
E \\
0 \\
+H \\
+6 \\
\times \quad E \\
E \\
10 \\
+\square\end{array}$ & 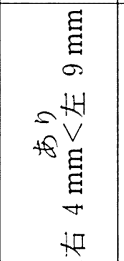 & 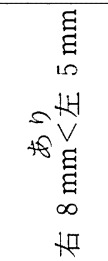 & 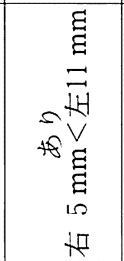 & 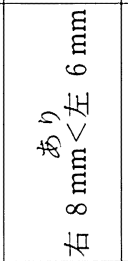 & 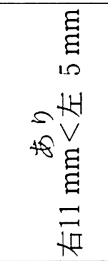 & 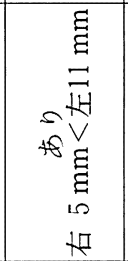 & 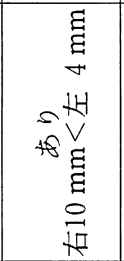 & 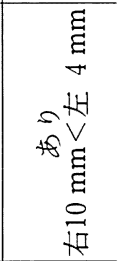 \\
\hline 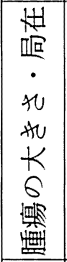 & 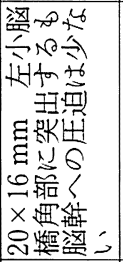 & 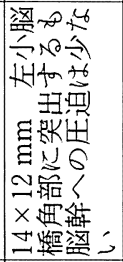 & 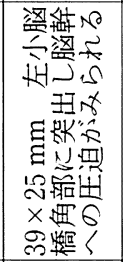 & 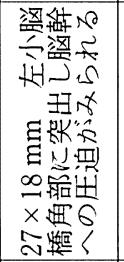 & 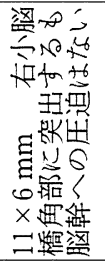 & 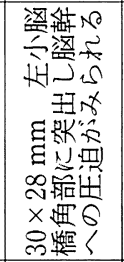 & 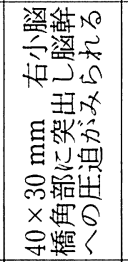 & 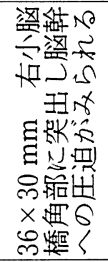 & 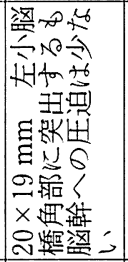 & 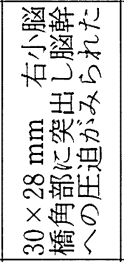 & 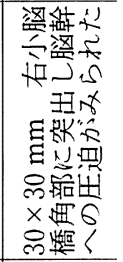 \\
\hline 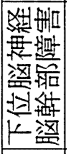 & \lrcorner & $\nu$ & 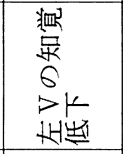 & $\begin{array}{r}- \\
+6\end{array}$ & $\begin{array}{l}-1 \\
+6\end{array}$ & 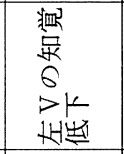 & 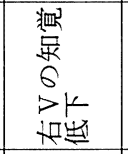 & $\begin{array}{r}-2 \\
+6\end{array}$ & 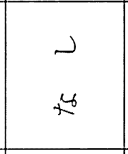 & $\begin{array}{l}-1 \\
+6\end{array}$ & -1 \\
\hline 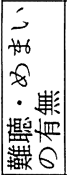 & 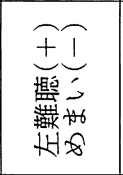 & 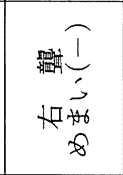 & 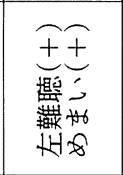 & 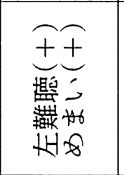 & 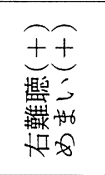 & 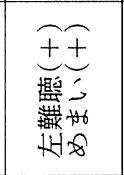 & 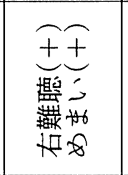 & 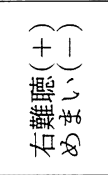 & 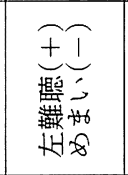 & 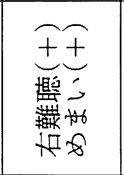 & 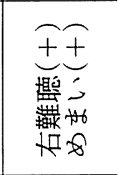 \\
\hline 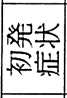 & 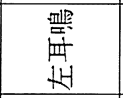 & 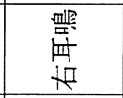 & $\begin{array}{l}3 \\
\ddot{x} \\
x\end{array}$ & 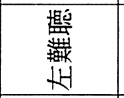 & 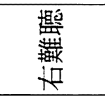 & 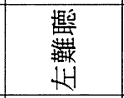 & 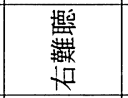 & 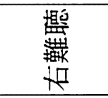 & 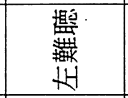 & 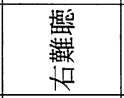 & 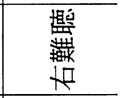 \\
\hline $\begin{array}{l}0<F \\
\text { 世 } 4 \text { स }\end{array}$ & 贲市 & 苏恋 & 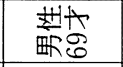 & $\begin{array}{l}\$+1 \\
+\infty \\
0\end{array}$ & $\begin{array}{l}\#+1 \\
\$ \times 0 \\
+\infty\end{array}$ & $\begin{array}{l}\text { W1 } \\
1 \times 10\end{array}$ & 贲亲要 & $\begin{array}{l} \pm 1+1 \\
1 \times 10\end{array}$ & 贲声 & $\frac{14}{1+}$ & 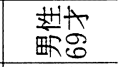 \\
\hline 䨢 & $\overrightarrow{\underline{⿱ 乛 龰}}$ & 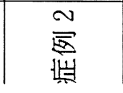 & $\underset{⿱ ㇒}{\infty}$ & 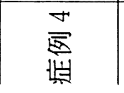 & $\underset{10}{10}$ & 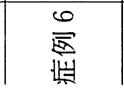 & 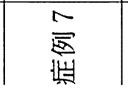 & 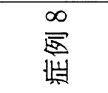 & 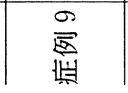 & 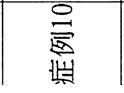 & 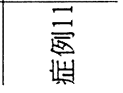 \\
\hline
\end{tabular}


出現するときには，既にかなりの大きさになっ ていることが多い，このとき第叫脳神経のみが 腫瘍に侵襲されていることは少なく, 他の脳神 経や小脳脳幹の障害が出現することが多い、今 回経験した非聴神経腫瘍 5 例はいずれも頭痛あ るいは侵襲された脳神経の症状を初発症状とし ており，また脳神経症状を随伴症状として認め た症例もあった。症例 1 では第 $\mathrm{V}$ 脳神経症状, 症例 3 では小脳脳幹障害, 症例 4 では第 $\mathrm{V}$, 第 VII脳神経症状を伴っていた。このことより第UII 脳神経症状を伴った非聴神経腫瘍はその性格上, 神経耳科学的精査とともに他の脳神経症状の検 討が必要であると思われた。

(2) 神経耳科学的検査所見

聴神経腫瘍は汪とんどが内耳道から発生し， 第UII脳神経に沿って発育し, bottle neck の様 に内耳道内の神経を圧迫したり，小脳橋角部に 侵入寸る (外側型) か, 時に, 内耳道孔部から の進展がみられることがある. (内側型 $)^{10)}$.こ のため聴神経腫瘍は，第UII脳神経の障害が主た る障害となっている．表 2 に示したよらに各症 例はなんらかの平衡機能系あるいは聴覚系の障 害が検査所見に認められた。これに対して，症 例 $1 ， 3 ， 4$ の非聴神経腫瘍に拀いても，平衡機 能検査では, 腫瘍による圧迫, 第叫脳神経の障 害により異常所見がみられたが，聴神経腫瘍と 明らかに鑑別できる所見は認められなかった。

聴覚系の検査では, 純音聴力検査で感音難聴 を呈したが，聴力レベルは症例 4 以外は軽度で あった．髄膜腫は聴神経腫瘍と比べ, 聴力レベ ルは軽度であると Laird らの報告もある111。 た，ABR は聴神経腫瘍をはじめとする小脳橋 角部腫瘍の診断に対して，有力な検査法である といわれている(2) 15)。これは，聴神経への直 接の圧迫による潜時の延長, また, 神経路の障 害による synchronization の障害によると考兄 られる16). 今回も症例 $1,2,3,4$ に拈いて， ABR に何らかの障害が認められた.

このよらに第UII脳神経を侵襲したり，小脳脳 幹を圧迫するよらな非聴神経腫瘍では, 神経耳
科学的検査に異常所見を認めた. 聴神経腫瘍と 比較すると聴力レベルの低下が軽度であったこ と以外，鑑別点を見いだすことは難しかった． 小松崎も, 機能検查所見では, 小脳橋角部髄膜 腫と聴神経腫瘍の鑑別は困難であり，前者は第 UII脳神経症状が比較的軽度であると報告してい $z^{17)}$.

（3）画像診断

耳鼻科において小脳橋角部に腫瘍の存在が疑 われた場合，一般的に，側頭骨単純レントゲン， 内耳道断層撮影, CT-scan が行われる. 内耳道 の拡大が明らかであれば，聴神経腫瘍の可能性 が高いが，実際には内耳道拡大を呈する髄膜腫 も少なくない18)。しかしながら今回経験した症 例 5 例に拈いては，すべて内耳道拡大は認めら れなかった。 air-CT は ear tumor の検索に非常 に有用ではあるが，非聴神経腫瘍との鑑別を行 らのは困難であり，また侵襲を伴い，検査後に 頭痛などの副作用も少なからず存在する.

近年，急速に進歩し，実用段階に入った MRI (Magnetic Resonance Imaging) は,小脳橋 角部も明瞭に描出でき，また無侵襲であること から，小脳橋角部腫瘍の精査にも用いられ，そ の有用性について報告がなされている19220)。実 際には, MRI は小脳橋角部腫瘍の鑑別におい て, specificity や sensitivityの点で CT より優 れているところがあるが，CT にとってかわる ほど明らかな優れた情報を提供していないのが 現沉である21)。しかしながら，䯣膜腫では T1， T2 の延長が聴神経腫瘍に比べ弱いことが特徵 とされて打り，より均一な造影効果をもつもの とされている18)。また Valvassori は Gd-DTPA を用いた MRI の有用性に期待して㧍り22)，実 際 Bauer らは髄膜腫での Gd-DTPA 使用の有 用性を報告している23)。今後, MRI の造影剂 （Gd-DTPA など）の開発, 空間分解能の向上 や高速スキャン法の発達に伴い,かつての CT, air-CT を中心とした診断法に比し，MRI を中 心とした画像診断により，小脳橋角部腫瘍の鑑 别診断に確実性を増すものと期待される. 
まとめ

小脳橋角部に発生した非聴神経腫瘍は，その 発生部位, 発育方向, 腫瘍の性状による圧迫に より様々な症状，検査所見を呈することが確認 された。したがって，画一的にその特徵を見い だすことは難しかった。

しかしながら，壮脳神経に侵襲がみられた非 聴神経腫瘍の場合, 聴神経腫瘍との鑑別が問題 とされ，その点について検討した。

1）聴神経腫瘍と鑑別を要した症例では, 初 発症状では, 頭痛や侵襲された脳神経の障害を 認め, 聴神経腫瘍によく認められる難聴, 耳鳴 といった症状はみられなかった。

2) 神経耳科学的検査には, 小脳橋角部や脳 幹圧迫を示す種々の異常所見を示したが, 腫瘍 の大きさに比して, 聴力レペルが軽度だった以 外, 聴神経腫瘍と明確に鑑別する所見は見い出 し難かった。

3）解像力に優れ, 非侵襲的に行える MRI は, 小脳橋角部腫瘍の診断において子重要な役 割を果たすものと期待される.

\section{参考文献}

1) Nager GT : Meningiomas of the cerebello-pontine angle and their relation to the temporal bone. Laryngoscope $80: 863 \sim 895,1970$.

2) Gonzalez Revilla A : Differential diagnosis of tumors at the cerebellopontine recess. Bull Johns Hopkins Hosp 83 : 187 212, 1948.

3）深谷 卓, 奥野妙子, 小松崎篤: 早期聴神経腫 瘍の発生部位と温度眼振反応について.日耳鼻 $86: 1461 \sim 1464,1983$.

4) Cushing $\mathrm{H}$ : Tumors of the nervus acusticus and the syndrome of the cerebellopontile angle. WB Saunders, Philadelphia, 1917.

5）水越鉄理：めまい. 平衡障害の客観化（情報処 理化)。めまい. 平衡障害の診断と治療一情報 処理システムを中心に一. 27〜 60頁, 現代医療 社, 1988.

6）水越鉄理：めむい平衡機能障害の情報処理シ ステム. 日耳鼻 $91:$ 1788〜 1795, 1988.

7) 北村勝俊, 松島俊夫, 福井仁士 : 聴神経腫瘍の 臨床〈臨床統計〉. 耳鼻咽喉科. 頭頸部外科
MOOK 10, 10～16頁, 金原出版, 1988.

8）坂田英治, 伊藤彰紀, 大都京子, 他 : 良性脳腫 瘍, とくに咀膜腫の外来診断要点. Equilibrium Res 41 : 1; 120 127, 1982.

9）趙 沛英: 小脳橋角部三腫瘍の鑑別診断につい て. 耳鼻臨床 $77: 695 \sim 705,1984$.

10) 吉本 裕 : 聴神経腫瘍の問診. 耳鼻咽喉科 - 頭 頸部外科 MOOK 10, 28 38頁, 金原出版, 1988.

11) Laird FJ, Harner SG, Laws ER, et al : Meningiomas of the cerebellopontine angle. Otolaryngol HNS 93 : 163 167, 1985.

12) Selters WA and Blackman DE : Acoustic tumor detection with brain stem electric response audiometry. Arch Otolaryngol 103 : 181 187, 1977.

13) Clemis JD and McGee $T$ : Brain stem electric response audiometry in the differential diagnosis of acoustic tumors. Laryngoscope $89: 31 \sim 42,1979$.

14) House JW and Brackmann DE : Brainstem audiometry in neurologic diagnosis. Arch Otolaryngol $105: 305 \sim 309,1979$.

15）細川 智, 北条和博, 戸田行雄, 他: 小脳橋角 部腫瘍症状に批ける聴性脳幹反応 (Brainstem Responses) について. 耳鼻臨床 $70: 107 \sim 113$, 1977.

16) Chinn $J$ and Miller $J$ : Animal model of acoustic neuroma. Arch Otolaryngol $101: 222$ $\sim 226,1975$.

17）小松崎篤：聴神経腫瘍以外の小脳橋角部病変. 内耳道病変の臨床. 311 333頁, 東京医学社, 1987.

18）塩野孝博, 吉川宏紀 : 聴神経腫膓の臨木 MRI. 耳鼻咽喉科・頭頸部外科 MOOK 10, 128 135 頁, 金原出版, 1988.

19) McGinnis BD, Brady TJ, New PFJ, et al : NMR imaging of tumors in the posterior fossa. J Comput Assist Tomogr 7 : 575 584, 1983.

20）船井洋光：MRI で発見された小脳橋角部腫瘍. JOHNS $4:$ 499 506, 1988.

21) Loneragan R, Fagan $P$, Tonkin JAM, et al : Magnetic resonance imaging evaluation of cerebellopontine angle tumors. Australas 
Radiol 33 : 47 55, 1989.

22) Valvassori GE : Cerebellopontine angle tumors. Otolaryngologic Clinics of North America 21 : 337 348, 1988.

23) Bauer WM, Fenzl G, Vogl $T$, et al : Indication for the use of Gd-DTPA in MRI of the central nervous system. Invest Radiology 23 Suppl

$1: 286 \sim 288,1988$.

(別刷請求先 : 安田健二

厂930-01 富山市杉谷 2630

富山医科薬科大学医学部耳鼻咽喉科学教室) 